\title{
Predominant Spastic Paraparesis Associated With the D178N Mutation in PRNP
}

Sebastian Thams, MD, PhD, * Martin Paucar, MD, PhD, * Louise Wingård, MD, PhD, Håkan Thonberg, PhD, Colin Smith, MD, PhD, Inger Nennesmo, MD, PhD, and Per Svenningsson, MD, PhD

Neurol Genet 2021;7:e636. doi:10.1212/NXG.0000000000000636

Spastic paraparesis is a very rare manifestation of prion diseases, occurring in both sporadic prion disease $^{1}$ and inherited prion disease. ${ }^{2}$ The $\mathrm{D} 178 \mathrm{~N}$ mutation in the prion protein (PRNP) gene is associated with familial fatal insomnia (FFI) or familial Creutzfeldt-Jakob disease (fCJD), ${ }^{3}$ and in some cases, FFI and fCJD overlap. ${ }^{4,5}$ Herein, we describe a patient harboring the $\mathrm{D} 178 \mathrm{~N}$ mutation in PRNP with initially predominant spastic paraparesis.

\section{Case Presentation}

A 70-year-old woman was admitted due to increasing dyspnea starting 6 months before admission. Relatives reported progressive gait difficulties, personality change, and frequent falls starting 2 months before admission. There were no signs of insomnia, but apnea during sleep was reported. She was a former smoker, investigations demonstrated mild emphysema and reduced FEV1\%, and the patient was diagnosed with mild COPD. Her saturation was normal (95\%) during ambient air breathing. Recurrent desaturation during sleep was noticed, but polysomnography (PSG) was not performed. OSA was diagnosed on these grounds, and the patient was treated with bronchodilators and CPAP, which alleviated dyspnea. On examination, spastic paraparesis, hyperreflexia, clonus, Babinski and Hoffman signs, and abnormal Romberg test were found. The patient could stand up only with support and was prone to fall backward. Two months after motor onset, the patient became a wheelchair user. The patient had confusion and apraxia; the Montreal Cognitive Assessment yielded 11 points, but her rapid deterioration prevented further cognitive assessment. Dyspnea and dysarthria worsened; imperative auditory hallucinations and dysphagia appeared early on. MRI of the brain with contrast revealed widespread white matter hyperintensities (WMHs) in subcortical areas and an incidental anterior communicating artery aneurysm. The WMHs were interpreted as angiopathic. In the left cerebellar hemisphere, 2 older small infarctions were found; the thalamus and the spinal cord had a normal appearance. Neuronal autoantibodies were absent; in her CSF, both cell number and albumin levels were normal, but neurofilament light protein and tau were elevated. In CSF, level of phosphorylated tau (p-tau) was within the reference range, resulting in a ratio $t$-tau/p-tau of $12.8, \beta 42$-amyloid was reduced, protein 14-3-3 was absent, and real-time quaking-induced conversion (RT-QuIC) for prion protein was negative (eTable 1 , links.lww.com/NXG/A488). Motor neuron disease was suspected, but repeated EMG and MEP studies performed twice were normal. The patient developed somnolence, became bedridden and anarthric, contracted recurrent pneumonias, and died 7 months after the onset of motor symptoms. The patient's next of kin authorized autopsy and provided consent for this report.

\author{
Correspondence \\ Dr. Paucar \\ martin.paucar-arce@sll.se
}


A
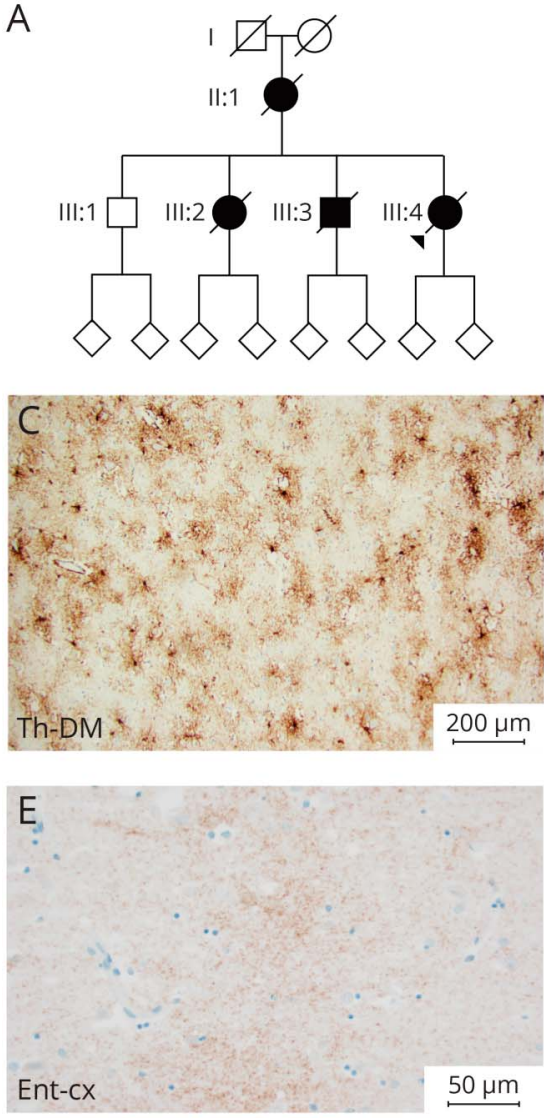

B
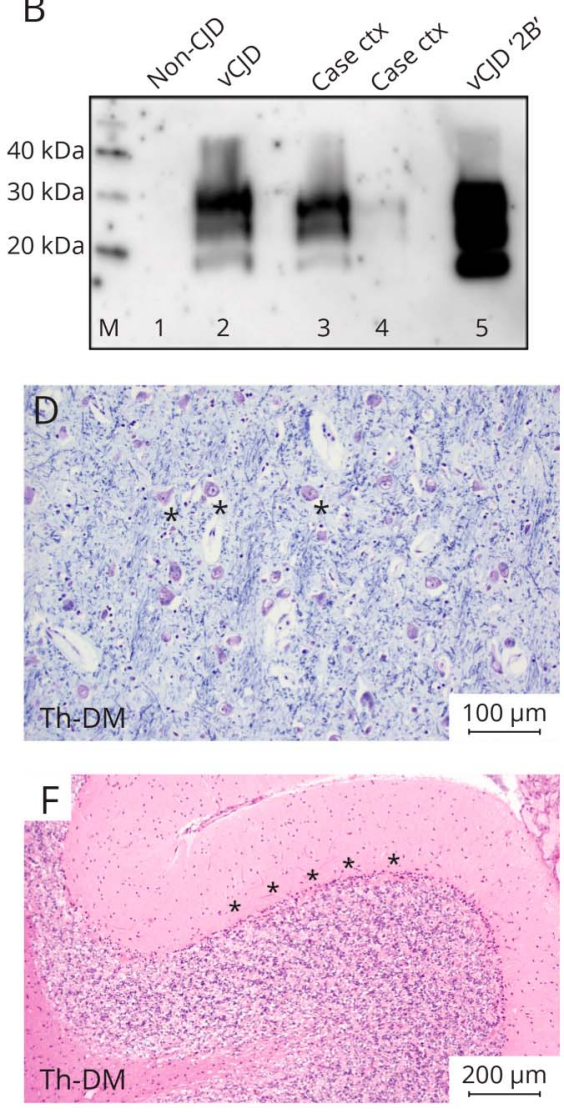

(A) The index case in a Spanish family (arrowhead) was affected with a late-onset and fast progressive neurodegenerative disease with prominent paraparesis. A genetic study revealed that she harbored the D178N mutation in PRNP. In addition, the neuropathologic assessment was compatible with familial fatal insomnia. (B) NaPTA Western blot analysis. M: magic marker; lane 1: unspiked NaPTA (500 $\mu \mathrm{L}$ of $10 \%$ brain homogenate-non-CJD case); lane 2: spiked NaPTA $(500 \mu \mathrm{L}$ of $10 \%$ brain homogenate-non-CJD case, spiked with $5 \mu \mathrm{L}$ vCJD $10 \%$ brain homogenate); lane 3: frontal cortex sample from case $(500 \mu \mathrm{L}$ of $10 \%$ brain homogenate); lane 4: frontal cortex sample-additional sample from case $(500 \mu \mathrm{L}$ of $10 \%$ brain homogenate); lane 5: positive control type 2B (3 $\mu \mathrm{L}$ vCJD $10 \%$ brain homogenate). (C) Immunostaining for glial fibrillary acidic protein (GFAP) on section from the medial part of the thalamus shows astrocytosis. (D) Luxol fast blue staining on a parallel section to $1 \mathrm{~B}$ shows the presence of several neurons indicated by asterisks. (E) Immunohistochemistry using the 12F10 antibody shows fine granular staining (brown) focally in the entorhinal cortex from the case. (F) Severe loss of Purkinje cells in the cerebellar cortex. The Purkinje cell layer is located below the asterisk. PRNP = prion protein.

\section{Family History and Genetic Analyses}

The patient (III:4) belonged to a family from the Castile region in Spain (Figure, A). One of her siblings (III:3), had died of a rapidly progressive disease, with anarthria and cognitive decline starting around age 35 years. The total course of disease in III:3 was 6 months, with a neuropathologic diagnosis of neuronal ceroid lipofuscinosis (Kufs disease). The neuropathologic report or charts were not possible to retrieve. Another sibling (III:2) and the patient's mother (II:1) had a similar course of disease with age at onset around 35 years; neuropathologic examinations were, however, not made.

Whole-genome sequencing (WGS) was performed, which ruled out mutations in genes associated with lipofuscinosis but revealed the heterozygous $\mathrm{D} 178 \mathrm{~N}$ mutation in PRNP, polymorphism $\mathrm{M} / \mathrm{V}$ at codon 129 , and $\mathrm{M}$ in cis with the mutated allele (supplementary material, links.lww.com/ NXG/A488).

\section{Neuropathology}

No macroscopic abnormalities were found on the cut surface except from prominent so-called Swiss cheese changes. The thalami were of normal size. Microscopically, astrogliosis in different thalamic nuclei (Figure, $\mathrm{C}$ ), especially in the medial nuclei, was found without prominent neuronal loss (Figure, D).
In the medulla oblongata, severe loss of neurons and severe astrogliosis were found in the inferior olivary nuclei. The pyramid tracts appeared to be of normal size, and the motor neurons of the hypoglossal nuclei were well preserved. Spongiform changes were not present in the brain. Immunohistochemistry with an antibody against prion protein, 12F10 (Bertin Bioreagent), showed weak synaptic staining in the entorhinal cortex (Figure, E). There was a marked loss of Purkinje cells in the cerebellum (Figure, F). The spinal cord was not available for examination. Western blot analysis of frozen brain tissue demonstrated a type $2 \mathrm{~B} \operatorname{PrP}$ isoform (Figure, B, lane 3) (supplementary document, links.lww. com/NXG/A488).

\section{Discussion}

Wide variability of age at onset and clinical features has been described for the D178N mutation., ${ }^{3,5,6,7, \mathrm{e} 1-\mathrm{e} 6}$ A polymorphism at codon 129 , either being valine $(\mathrm{V})$ or a methionine (M), has been proposed as a strong modulator of the $\mathrm{D} 178 \mathrm{~N}$ mutation, with $129 \mathrm{~V}$ on the same allele of the mutation associated with $\mathrm{FCJD}$, whereas $129 \mathrm{M}$ is associated with FFI. $^{3}$ Our case displays the typical neuropathologic abnormalities for FFI. It is important that homozygosity $129 \mathrm{M}$ is 
usually associated with shorter disease duration compared with heterozygotes. ${ }^{\text {e3 }}$ However, this association has been challenged. $^{4,5, \mathrm{e} 5}$ Short disease duration, despite $129 \mathrm{MV}$, and the initial predominant spastic paraparesis stand out in our case. Brain MRI studies may contribute when investigating prion phenotypes such as fCJD associated with $\mathrm{E} 200 \mathrm{~K}^{\mathrm{e} 7}$ but not cases with the D178N mutation. Furthermore, 14-3-3 is rarely positive in patients with the $\mathrm{D} 178 \mathrm{~N}$ mutation. ${ }^{5} \mathrm{Nega}$ tive RT-QuIC for prion protein in our case contrasts with the high yield $(83.3 \%)$ in a previous study. ${ }^{\text {e }}$ Only once has irregular sleep pattern, but no apnea, been reported in $\mathrm{D} 178 \mathrm{~N}$. $^{5}$ This work has some limitations; PSG and dysautonomia tests were not performed due to the absence of insomnia and because dyspnea was interpreted as a COPD manifestation. Thus, central apnea may have been missed in our case. Another limitation is that the spinal cord was not available for examination. Finally, our serendipitous diagnosis illustrates the utility of WGS when investigating familial neurodegenerative diseases.

\section{Acknowledgment}

The authors are grateful to the patient's next of kin for consenting to this publication and to Dr. Rodrigo Bernaldo de Quirós in Spain. The authors are also grateful to Dr. Nicola Carrol in Edinburgh for performing allele analysis at codon 129.

\section{Study Funding}

No targeted funding reported.

\section{Disclosure}

The authors report no disclosures relevant to the manuscript. Go to Neurology.org/NG for full disclosures.

\section{Publication History}

Received by Neurology: Genetics November 8, 2020. Accepted in final form September 15, 2021.
Appendix Authors

\begin{tabular}{|c|c|c|}
\hline Name & Location & Contribution \\
\hline $\begin{array}{l}\text { Sebastian } \\
\text { Thams, MD, } \\
\text { PhD }\end{array}$ & $\begin{array}{l}\text { Karolinska University } \\
\text { Hospital and Karolinska } \\
\text { Institutet, Stockholm }\end{array}$ & $\begin{array}{l}\text { Patient care and } \\
\text { investigation, study concept } \\
\text { and design, analysis and } \\
\text { interpretation of data, and } \\
\text { editing of the manuscript }\end{array}$ \\
\hline $\begin{array}{l}\text { Martin Paucar, } \\
\text { MD, PhD }\end{array}$ & $\begin{array}{l}\text { Karolinska University } \\
\text { Hospital and Karolinska } \\
\text { Institutet, Stockholm }\end{array}$ & $\begin{array}{l}\text { Analysis and interpretation } \\
\text { of clinical data and writing } \\
\text { the first draft }\end{array}$ \\
\hline $\begin{array}{l}\text { Louise } \\
\text { Wingård, MD, } \\
\text { PhD }\end{array}$ & $\begin{array}{l}\text { Department of Psychiatry, } \\
\text { North West area in } \\
\text { Stockholm }\end{array}$ & $\begin{array}{l}\text { Patient care and } \\
\text { investigation and editing of } \\
\text { the manuscript }\end{array}$ \\
\hline $\begin{array}{l}\text { Håkan } \\
\text { Thonberg, MD, } \\
\text { PhD }\end{array}$ & $\begin{array}{l}\text { Karolinska Institutet and } \\
\text { Karolinska University } \\
\text { Hospital, Stockholm }\end{array}$ & $\begin{array}{l}\text { Interpretation of genetic data } \\
\text { and editing of the manuscript }\end{array}$ \\
\hline $\begin{array}{l}\text { Colin Smith, } \\
\text { MD, PhD }\end{array}$ & $\begin{array}{l}\text { National CJD Research \& } \\
\text { Surveillance Unit, } \\
\text { Edinburgh }\end{array}$ & $\begin{array}{l}\text { Analysis of prion protein } \\
\text { strain in brain tissue and } \\
\text { editing of the manuscript }\end{array}$ \\
\hline $\begin{array}{l}\text { Inger } \\
\text { Nennesmo, } \\
\text { MD, PhD }\end{array}$ & $\begin{array}{l}\text { Karolinska University } \\
\text { Hospital, Stockholm }\end{array}$ & $\begin{array}{l}\text { Neuropathologic } \\
\text { assessment, study concept, } \\
\text { and editing of the manuscript }\end{array}$ \\
\hline $\begin{array}{l}\text { Per } \\
\text { Svenningsson, } \\
\text { MD, PhD }\end{array}$ & $\begin{array}{l}\text { Karolinska University } \\
\text { Hospital and Karolinska } \\
\text { Institutet, Stockholm }\end{array}$ & $\begin{array}{l}\text { Supervision, analysis and } \\
\text { interpretation of data, and } \\
\text { editing of the manuscript }\end{array}$ \\
\hline
\end{tabular}

\section{References}

1. Jansen C, Head MW, van Gool WA, et al. The first case of protease-sensitive prionopathy (PSPr) in The Netherlands: a patient with an unusual GSS-like clinical phenotype. J Neurol Neurosurg Psychiatry. 2010;81(9):1052-1055.

2. Kitamoto T, Amano N, Terao Y, et al. A new inherited prion disease (PrP-P105L mutation) showing spastic paraparesis. Ann Neurol. 1993;34(6):808-813.

3. Gambetti P, Parchi P, Petersen RB, Chen SG, Lugaresi E. Fatal familial insomnia and familial Creutzfeldt-Jakob disease: clinical, pathological and molecular features. Brain Pathol. 1995;5(1):43-51.

4. Zerr I, Giese A, Windl $\mathrm{O}$, et al. Phenotypic variability in fatal familial insomnia (D178N-129M) genotype. Neurology. 1998;51(5):1398-1405.

5. Zarranz JJ, Digon A, Atarés B, et al Phenotypic variability in familial prion diseases due to the D178N mutation. J Neurol Neurosurg Psychiatry. 2005;76(11):1491-1496.

6. Lugaresi E, Medori R, Montagna P, et al. Fatal familial insomnia and dysautonomia with selective degeneration of thalamic nuclei. N Engl J Med. 1986;315(16):997-1003.

7. Parchi P, Petersen RB, Chen SG, et al. Molecular pathology of fatal familial insomnia. Brain Pathol. 1998;8(3):539-548.

eReferences e1-e10 are available at: links.lww.com/NXG/A488. 


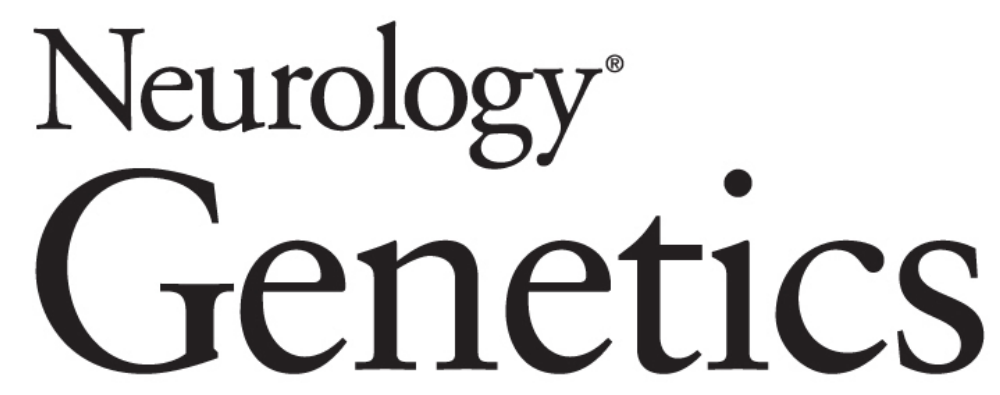

\section{Predominant Spastic Paraparesis Associated With the D178N Mutation in PRNP Sebastian Thams, Martin Paucar, Louise Wingård, et al. Neurol Genet 2021;7; \\ DOI 10.1212/NXG.0000000000000636}

This information is current as of November 4, 2021

$\begin{array}{ll}\begin{array}{l}\text { Updated Information \& } \\ \text { Services }\end{array} & \begin{array}{l}\text { including high resolution figures, can be found at: } \\ \text { http://ng.neurology.org/content/7/6/e636.full.html }\end{array} \\ \text { References } & \text { This article cites } 7 \text { articles, } 2 \text { of which you can access for } \\ \text { http://ng.neurology.org/content/7/6/e636.full.html\#\#ref-list- } & \text { This article, along with others on similar topics, appears } \\ \text { following collection(s): } & \begin{array}{l}\text { All Genetics } \\ \text { http://ng.neurology.org//cgi/collection/all_genetics } \\ \text { Prion disease; see Infections/prion }\end{array} \\ & \text { http://ng.neurology.org//cgi/collection/prion_disease } \\ & \text { Spastic paraplegia } \\ \text { http://ng.neurology.org//cgi/collection/spastic_paraplegia } & \\ & \text { Information about reproducing this article in parts (figures, } \\ & \text { its entirety can be found online at: } \\ \text { http://ng.neurology.org/misc/about.xhtml\#permissions } & \text { Information about ordering reprints can be found online: } \\ \text { Permissions \& Licensing } & \text { http://ng.neurology.org/misc/addir.xhtml\#reprintsus }\end{array}$

Neurol Genet is an official journal of the American Academy of Neurology. Published since April 2015, it is an open-access, online-only, continuous publication journal. Copyright Copyright $\odot 2021$ The Author(s). Published by Wolters Kluwer Health, Inc. on behalf of the American Academy of Neurology.. All rights reserved. Online ISSN: 2376-7839.

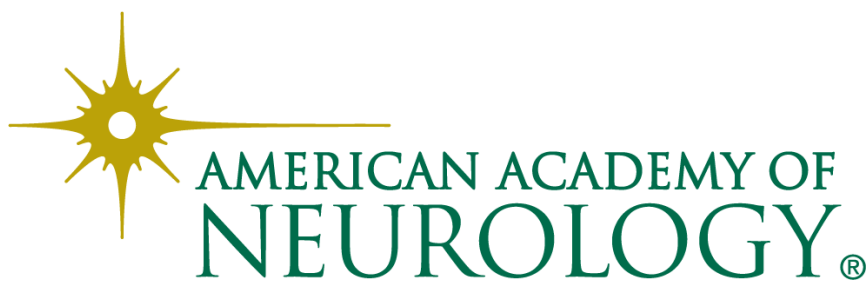

